\title{
PENERAPAN MODEL PEMBELAJARAN INKUIRI TERBIMBING UNTUK MENINGKATKAN KETERAMPILAN PROSES SAINS DAN HASIL BELAJAR PESERTA DIDIK DI KELAS IX-G SMP NEGERI 1 STABAT KAB. LANGKAT T.P. 2018/2019
}

\author{
Suriyadi \\ Guru IPA SMP Negeri 1 Stabat \\ JIn.K.H.Z. Arifin Stabat, Kwala Bingai, Kec. Stabat, Kab. Langkat Prov. Sumatera Utara \\ *Korespondensi Author: Suriyadiandi@gmail.com
}

\author{
INFOARTIKEL \\ Histori Artikel \\ Received 22 November 2019 \\ Revised 24 November 2019 \\ Accepted 25 November 2019 \\ Published 28 November 2019 \\ Keywords: \\ Penelitian tindakan kelas, \\ inkuiri terbimbing, \\ keterampilan proses sains
}

\begin{abstract}
The purpose of this study was to determine the improvement of science process skills and student learning outcomes after the application of the guided inquiry learning model in class IX-G of SMP Negeri 1 Stabat. Classroom action research (CAR) in the form of initial reflection activities and observations to identify problems that occur in class, learning planning, action implementation, observation and reflection. The PTK research findings are in the first cycle of class completeness of $71.9 \%$ and incomplete by $28.1 \%$, with an average of 71.4. In cycle II student learning outcomes obtained $90.6 \%$ completeness and $9.4 \%$ incomplete with an average of 78.03 . The science process skills in the first cycle, from the 4 aspects assessed 3 aspects namely observing, collecting data and concluding are still in the sufficient category while the communicating aspect is in a good category. In cycle II, out of the 4 aspects assessed 2 aspects had very good categories namely observing aspects and communicating aspects, 2 aspects having good categories namely analyzing data aspects and communicating aspects. So that conclusions can be drawn from the application of inquiry learning models in class IX-G of SMP Negeri 1 Stabat, Kab. Langkat T.P. 2018/2019 can improve science process skills and student learning outcomes.
\end{abstract}

Copyright (C) 2019 Universitas Negeri Medan. Artikel Open Access dibawah lisensi CCBY-4.0 (https://creativecommons.org/licenses/by/4.0)

\section{How To Cite:}

Suriyadi. (2019). Penerapan Model Pembelajaran Inkuiri Terbimbing Untuk Meningkatkan Keterampilan Proses Sains Dan Hasil Belajar Peserta Didik Di Kelas Ix-G SMP Negeri 1 Stabat Kab. Langkat T.P. 2018/2019. Jurnal Pelita Pendidikan, 7(3), 121-125. 


\section{PENDAHULUAN}

Keterampilan Proses Sains (KPS) adalah keterampilan yang melibatkan keterampilan kognitif atau intelektual, manual dan sosial. Keterampilan kognitif terlibat karena dengan melakukan keterampilan proses peserta didik menggunakan pikirannya. Keterampilan proses sains sangat penting dimiliki oleh peserta didik untuk menghadapi persaingan di era globalisasi yang menuntut persaingan antar manusia. Nandang, R (2009) mengutarakan bahwa era globalisasi yang berlangsung menuntut peserta didik untuk dapat menyelesaikan masalah yang bersifat spesifik dan juga mampu mengoptimalkan kemampuan kognitif (cognitive tools) serta berbagai kompetensi lainnya. Sehubungan dengan hal tersebut, Dahar, R.W (1996), keterampilan proses sains (KPS) adalah kemampuan peserta didik untuk menerapkan metode ilmiah dalam memahami, mengembangkan dan menemukan ilmu pengetahuan. KPS sangat penting bagi setiap peserta didik sebagai bekal untuk menggunakan metode ilmiah dalam mengembangkan sains serta diharapkan memperoleh pengetahuan baru atau mengembangkan pengetahuan yang telah dimilik

Selain itu, beberapa alasan yang yang melandasi perlunya keterampilan proses sains dalam kegiatan belajar mengajar dikemukakan oleh Semiawan, (2002) bahwa peserta didik lebih mudah memahami konsep rumit dan abstrak jika disertai dengan contoh konkret atau melalui benda nyata, sehingga peserta didik belajar secara aktif dan kreatif dalam mengembangkan keterampilan untuk memproseskan perolehan konsep. Lebih lanjut Semiawan mengungkapkan bahwa keterampilan proses sains sangat penting diterapkan dalam proses belajar mengajar agar anak dapat berlatih untuk selalu bertanya, berpikir kritis, menumbuh kembangkan keterampilan fisik dan mental, serta sebagai wahana untuk menyatukan pengembangan konsep peserta didik dengan pengembangan sikap dan nilai yang penting sebagai bekal terhadap tantangan di era globalisasi.

Meskipun demikian, kenyataan di dunia pendidikan keterampilan proses sains belum dikembangkan secara optimal khususnya di SMP Negeri 1 Stabat Kab Langkat pada tahun pelajaran 2018/2019. Tidak terfasilitasinya penerapan KPS khsususnya pada mata pelajaran IImu Pengetahuan
Alam (IPA) dikarenakan guru kurang memahami langkah-langkah keterampilan proses sains yang diaplikasikan dalam pembelajaran maupun dalam praktikum. Pengembangan keterampilan proses sains baik dalam proses pembelajaran maupun evaluasi hasil belajar sangat jarang dilakukan, sehingga peserta didik kurang mampu mengembangkan keterampilan dalam menemukan dan menghubungkan konsep yang akan diperoleh.

Dilihat dari hasil belajar IPA pada ulangan harian pada semester satu tahun pelajara 2018/2019 juga menunjukkan sekitar 60\% peserta didik tidak tuntas Kriteria Belajar Minimal (KBM) yang ditetapkan yaitu 75 , sehingga guru melakukan remedial dalam proses belajar mengajar. Mengingat pentingnya keterampilan keterampilan proses sains dan peningkatan hasil belajar peserta didik. Menurut Blosser, E.P. (1973), proses pembelajaran sains cenderung menekankan pada pemberian pengalaman langsung untuk mengembangkan kompetensi dan menumbuhkan kemampuan berfikir. Pembentukan sikap ilmiah seperti ditunjukan oleh para ilmuwan sains dapat dikembangkan melalui keterampilan-keterampilan proses sains. Sehingga keterampilan proses sains, dapat digunakan sebagai pendekatan dalam pembelajaran

Maka diperlukan model pembelajaran yang dapat memfasilitasi terselenggaranya kegiatan pembelajaran yang mampu mengembangkan keterampilan proses sains peserta didik. Salah satu model pembelajaran yang diharapkan dapat mengembangkan keterampilan proses sains peserta didik adalah pembelajaran dengan menggunakan model pembelajaran inkuiri terbimbing (guided inquiry).

Penerapan model pembelajaran ini menurut, Paidi (2007) menerangkan guide inkuiry/Inkuiri terbimbing sebagai kegiatan dimana peserta didik diberikan kesempatan untuk bekerja merumuskan prosedur, menganalisis hasil, dan mengambil kesimpulan secara mandiri, sedangkan dalam hal menentukan topik, pertanyaan, dan bahan penunjang, guru hanya sebagai fasilitator.

Model pembelajan inkuiri terbimbing merupakan posisi guru membimbing peserta didik dengan melakukan kegiatan dengan memberi pertanyaan awal dan mengarahkan pada suatu diskusi. Guru mempunyai peran aktif dalam 
menentukan permasalahan dan tahap-tahap pemecahannya. Dalam model pembelajaran ikuiri terbimbing peserta didik tidak hanya mencari dan menemukan pengetahuan sebagai solusi untuk memecahkan masalah tetpi peserta didik juga dapat memahami pembelajaran sehingga tercipta kegiatan yang variatif sehingga dapat memotivasi peserta didik.

Sedangan menurut Hamruni (2012) menyatakan sebagai berikut: 1) Menekankan kepada aktivitas peserta didik untuk mencari dan menemukan; 2) Aktivitas belajar peserta didik diarahkan untuk mencari dan menemukan sendiri jawaban dari sesuatu yang dipertanyakan sehingga dapat menumbuhkan sikap percaya diri; 3) Mengembangkan kemampuan berfikir secara sistematis, logis dan kritis.

Adapun tujuan dari penelitian tindakan kelas ini adalah: 1) Memberikan gambaran tentang rencana pelaksanaan pembelajaran yang disusun dengan menggunakan model inkuiri terbimbing; 2 ) Untuk mengetahui peningkatan keterampilan proses sains peserta didik setelah penerapan model pembelajaran ikuiri terbimbing di kelas IX-G SMP Negeri 1 Stabat Kab. Langkat T.P. 2018/2019; 3) Untuk mengetahui peningkatan hasil belajar peserta didik setelah penerapan model pembelajaran ikuiri terbimbing di kelas IX-G SMP Negeri 1 Stabat Kab. Langkat T.P. 2018/2019.

\section{METODE PENELITIAN}

Metode yang digunakan dalam penelitian ini adalah penelitian tindakan kelas, desain PTK merupakan kegiatan pemecahan masalah yang bercirikan siklik dan reflektif yang dimulai dari 1 ) perencanaan (planning), 2) pelaksanaan tindakan (action), 3) mengumpulkan data (observing), dan 4) menganalisis data atau informasi untuk memusatkan sejauh mana kelebihan atau kelemahan tindakan tersebut.

\section{HASIL DAN PEMBAHASAN}

Penelitian Tindakan Kelas yang dilaksanakan untuk meningkatkan hasil belajar siswa dengan menerapkan model pembelajaran inkuiri terbimbing 'mata pelajaran IPA kelas IX-G SMP Negeri 1 Stabat Tahun Pelajaran 2018/2019. Sebelum melaksanakan penelitian siklus I dilakukan langkah-langkah yang dilakukan peneliti yaitu: 1) menyusun rancangan pelaksanaan pembelajaran (RPP), 2) Instrumen penilaian keterampilan proses sains, 3) sumber belajar, dan bahan yang dibutuhkan dalam melaksanakan pembelajaran, dan 4) membuat tes untuk mengukus kemampuan kognitif siswa.

\section{Siklus I}

Proses belajar mengajar menggunakan model inkuiri terbimbing yang dilakukan pada materi Pewarisan Sifat di kelas IX-G SMP Negeri I Stabat dengan Kriteria Belajar Minimal Mata pelajaran IPA $(K B M=75)$ diperoleh hasil belajar siswa tertera pada gambar. 1 dibawah ini.

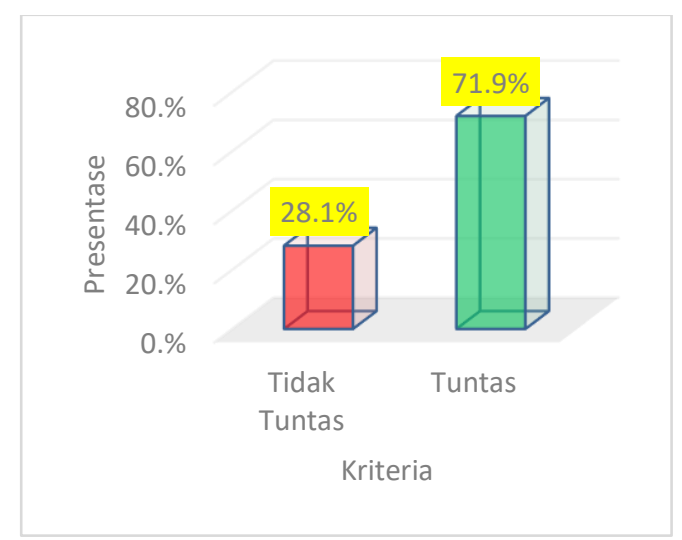

Gambar 1. Hasil Belajar IPA Siklus I 
Dari gambar 1 diatas diperoleh hasil belajar IPA kelas IX-G SMP Negeri 1 Langkat Tahun Pelajaran 2018/2019, dapat ditarik kesimpulan bahwa pembelajaran dengan menggunakan model pembelajaran Inkuiri terbimbing untuk meningkatkan hasil belajar dari 32 orang siswa diperoleh 23 orang yang tuntas atau sekitar $71,9 \%$ dan 9 orang yang tidak tuntas atau sekitar $28,1 \%$, dengan rerata 71,4 . Pada siklus I ini dilihat dari ketuntasan klasikal belum terpenuhi hasil observasi ditemukan bahwa siswa belum terbiasa menerapkan model pembelajaran inkuiri untuk meningkatkan keterampilan proses, hal ini selajan dengan pendapat Simatupang, H. (2014) yang mengatakan keterampilan proses harus benarbenar melibatkan peserta didik dalam prosesnya.

Keterampilan proses sains siswa dalam 5 kelompok dari 4 aspek yang dinilai 3 aspek yaitu mengamati, mengumpulkan data dan menyimpulkan masih dalam kategori cukup sedangkan pada aspek mengkomunikasikan sudah masuk kategori baik. Temuan-temuan ini menjadi masukan perbaikan pada siklus II.

\section{Siklus II}

Perencanaan siklus II berdasarkan kendala dan kelemahan yang ditemukan pada siklus I dan dari hasil observasi keterampilan proses sains siswa dalam penerapan model pembelajaran inkuiri terbimbing, agar kendala dan kelemahan pada siklus I tidak terjadi lagi maka guru berupaya semaksimal mungkin untuk mengontrol kegiatan proses belajar mengajar dan memberikan motivasi kepada siswa. Hasil belajar siswa tertera pada gambar 2 dibawah ini

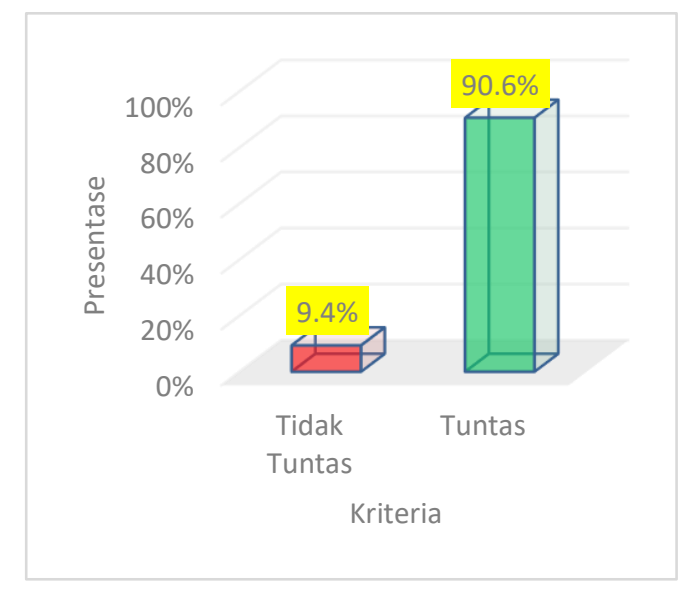

Gambar 2. Hasil Belajar IPA Siklus II

Dari gambar 2 diatas diperoleh hasil belajar IPA kelas IX-G SMP Negeri 1 Stabat Tahun Pelajaran 2018/2019, dapat ditarik kesimpulan bahwa pembelajaran dengan menggunakan model pembelajaran Inkuiri terbimbing untuk meningkatkan hasil belajar dari 32 orang siswa diperoleh 29 orang yang tuntas atau sekitar 90,6\% dan 3 orang yang tidak tuntas atau sekitar $9,4 \%$ dengan rata-rata 78,03 . Secara ketuntasan klasikal pada siklus II ini diketahui bahwa kelas IX-G telah mengalami ketuntasan klasikal karena telah melewati 85\% sesuai pendapat Asnita, (2013) mengatakan interval daya serap klasikal $85 \%$ tergolong tinggi.

Dapat ditarik kesimpulan bahwa model pembelajaran inkuiri dapat meningkatkan hasil belajar IPA sejalan dengan hasil penelitian ini didukung hasil penelitian Setiawan (2005); Winarni (2006). Kedua penelitian ini menunjukkan bahwa penerapan pembelajaran dengan metode inkuiri terbimbing dapat meningkatkan pemahaman konsep dan hasil belajar kognitif siswa. Keterlibatan aktif siswa dalam belajar akan meningkatkan hasil belajarnya.

Untuk keterampilan proses sains siswa dalam 5 kelompok dari 4 aspek yang dinilai 2 aspek yaitu memiliki kategori sangat baik yaitu aspek mengamati dan aspek mengkomunikasikan, 2 aspek memiliki kategori baik yaitu aspek menganalisis data dan aspek mengkomunikasikan. Keterampilan proses sains ini meningkat dikarenakan pada siklus II perbaikan ditikankan aspek-aspek yang kurang.

Peningkatan ini dikarenakan guru berperan aktif 
dalam membimbing siswa dalam proses belajar mengajar dan mengawasi jalannya percobaan bahkan sesekali guru memberi saran jalannya percobaan hal ini sama dengan pendapat (Roestiyah, 2001), guru mengawasi pekerjaan siswa, bila perlu memberikan saran yang menunjang kesempurnaan jalannya diskusi/eksperimen dalam proses belajar mengajar.

\section{KESIMPULAN}

Pada siklus I dari 32 orang siswa diperoleh 23 orang yang tuntas dengan $71,9 \%$ dan 9 orang yang tidak tuntas dengan $28,1 \%$, dengan rerata 71,4 . Pada siklus II hasil belajar diperoleh 32 orang siswa diperoleh 29 orang yang tuntas dengan $90,6 \%$ dan 3 orang yang tidak tuntas dengan $9,4 \%$ dengan rerata 78,03 . Peningkatan keterampilan proses sains dari siklus I dari 5 kelompok dari 4 aspek yang dinilai 3 aspek yaitu mengamati, mengumpulkan data dan menyimpulkan masih dalam kategori cukup sedangkan pada aspek mengkomunikasikan sudah masuk kategori baik. Meningkat pada siklus II menjadi dari 5 kelompok dari 4 aspek yang dinilai 2 aspek yaitu memiliki kategori sangat baik yaitu aspek mengamati dan aspek mengkomunikasikan, 2 aspek memiliki kategori baik yaitu aspek menganalisis data dan aspek mengkomunikasikan.

\section{DAFTAR PUSTAKA}

Sri Anitah and Hernawan, Asep Herry and Ruhiat, Toto, 2007. Strategi Pembelajaran di SD. Jakarta: Universitas Terbuka.

Sabri, Ahmad .2005. Strategi Belajar Mengajar. Jakarta: Quantum teaching

Amir, M. T. (2015). Inovasi Pendidikan Melalui Problem Based Learning. Jakarta: Prenada media Group.

Hernawan, H . 2007. Belajar dan Pembelajaran SD. Bandung: UPI Press.

OECD. 2013. PISA 2015 Draft Science Framework. Diakses dari http://www.oecd.org/pisa/pisaproduc ts/Draft\%20PISA\%202015\%20Science \%20Framework\%20.pdf pada tanggal 13 November 2017
Simatupang, H., Aryeni, Purnama, D. 2017. Peningkatan Kemampuan Literasi Sains Mahasiswa Melalui Penerapan Model Problem Solving Laboratory Pada Matakuliah Praktikum Biologi Sistem. Jurnal Pelita Pendidikan Vol. 5 No. 2.

Roestiyah, N.K. 2012. Strategi Belajar Mengajar. Jaarta: Rineka Cipta.

TPPI. 2013. OECD: Siswa Indonesia Merupakan Siswa Yang Paling Bahagia Di Dunia. Diakses dari http://thepresident postindonesia.com/2013/12/08/-

oecd- siswa-indonesia-merupakansiswa-yang-paling-bahagia-di-dunia/ pada tanggal 1 November 2017 